\title{
Only 5 southern Greenland shelf edge glaciations since the early Pliocene
}

SUBJECT AREAS:

PALAEOCLIMATE

GEOLOGY

CRYOSPHERIC SCIENCE

CLIMATE CHANGE

Received

14 February 2013

Accepted

25 April 2013

Published

23 May 2013

Correspondence and requests for materials should be addressed to T.N. (tni@geus.dk) or A.K. (aku@geus.dk)
Tove Nielsen \& Antoon Kuijpers

Geological Survey of Denmark and Greenland, Øster Voldgade 10, 1350 Copenhagen K, Denmark.

Much uncertainty exists about the history of the Greenland Ice Sheet (GIS), particularly as to the frequency of extreme shelf edge glaciations. Because the last glaciation removed most of the record of earlier GIS extent on land and shelf exploration of the older GIS glacial record requires the use of deeper marine archives. Here we present seismic evidence for the frequency of extreme shelf edge glaciations offshore southwest Greenland. Our findings reveal that since the GIS formation only 5 glaciations were characterized by an ice sheet covering the entire shelf of southern Greenland. We estimate an age of around 4.5 million years $(\mathrm{my})$ for the oldest episode and found that such extreme GIS expansions may have occur here only 3 times within the past c. $1.5 \mathrm{my}$. We thus conclude that the first large shelf edge glaciation of southern Greenland did occur prior to the Pliocene warmth epoch.

ocumentation of ice-rafted debris (IRD) demonstrates the existence of Northern Hemisphere ice sheets back to at least $10 \mathrm{my} \mathrm{ago}{ }^{1,2}$, though glaciers on Greenland may have existence already 20 my earlier ${ }^{3}$. As the Greenland ice core record is limited to the last glacial cycle ${ }^{4}$, the history of the GIS before this time is only known from scattered and fragmentary geological information. Only in very few places older glacial deposits are found on land or on the inner shelf ${ }^{5,6}$. In contrast, the outer Greenland shelf and slope are characterized by large prograding wedges of glacigenic sediments deposited by multiple ice streams ${ }^{7}$, documenting the existence of former large-scale ice sheet expansions. The greater part of the wedges is formed by down-slope mass-flow deposits triggered every time the ice reached the (paleo-) shelf edge, the so-called glacigenic debris flows $(\mathrm{GDF})^{8}$. The wedges are the cumulative and amalgamated result of multiple shelf glaciations. Identification and discrimination of GDF units from individual glaciations is difficult, not only on the shelf, but also in upper slope areas where extreme ice sheet conditions led to calving of giant, deep-draft icebergs scouring the seabed down to about $1000 \mathrm{~m}$ of water depth ${ }^{9}$. In contrast, in the adjacent deep water areas away from direct ice contact, records from the most extreme shelf edge glaciations may be preserved owing to a long run-out potential of the $\mathrm{GDF}^{8} \mathrm{~s}^{8}$. A first prerequisite for tracing here extreme shelf-edge glaciation through time is a marked difference between glacial and inter-glacial depositional environments. We have found that the basinal area off the glaciated southwest Greenland margin bordering the Davis Strait Drift Complex $\left(D_{S D C}{ }^{10}\right)$ toward west fulfils these conditions (Fig. 1a). In extreme glacial periods this basin is dominated by the GDF deposition, in contrast to DSDC current dominated deposition during interglacial periods.

The thermohaline circulation regime is known to fluctuate with the glacial-interglacial cycles ${ }^{11}$. The presentday oceanographic setting of the study area is characterized by significant boundary current activity both at shallow depth (north flowing West Greenland Current) and greater depth (Fig. 1b, inset map) ${ }^{11}$. This current system has been responsible for the formation of the DSDC since mid Miocene times ${ }^{10}$. An oceanographic setting similar to the present-day may be expected in interglacial times, while a current slow-down and change of the circulation pattern occurred in glacial times ${ }^{5,12}$.

\section{Results}

Based on a dense grid of conventional 2D seismic data (Fig. 1b; see Methods), our study is the first to report the frequency of extreme southern Greenland shelf edge glaciations. Stratigraphic information has been derived from a published seismo-stratigraphy of the $\mathrm{DSDC}^{10}$. The architectural development of the basin deposits is studied by identifying intervals representative for a prevalence of either current- or glacial-related processes. The seismic identification of the two resulting depositional types is based on reflection pattern variations (see Methods). We present here examples of multi-channel seismic profiles (Figs. 2,3) showing the alternation of units mainly representative of a contourite facies and intercalated several major GDF units. The number of major GDF units in southern Davis Strait is constant (five), whereas at least six or seven major GDF units can be observed in sections 

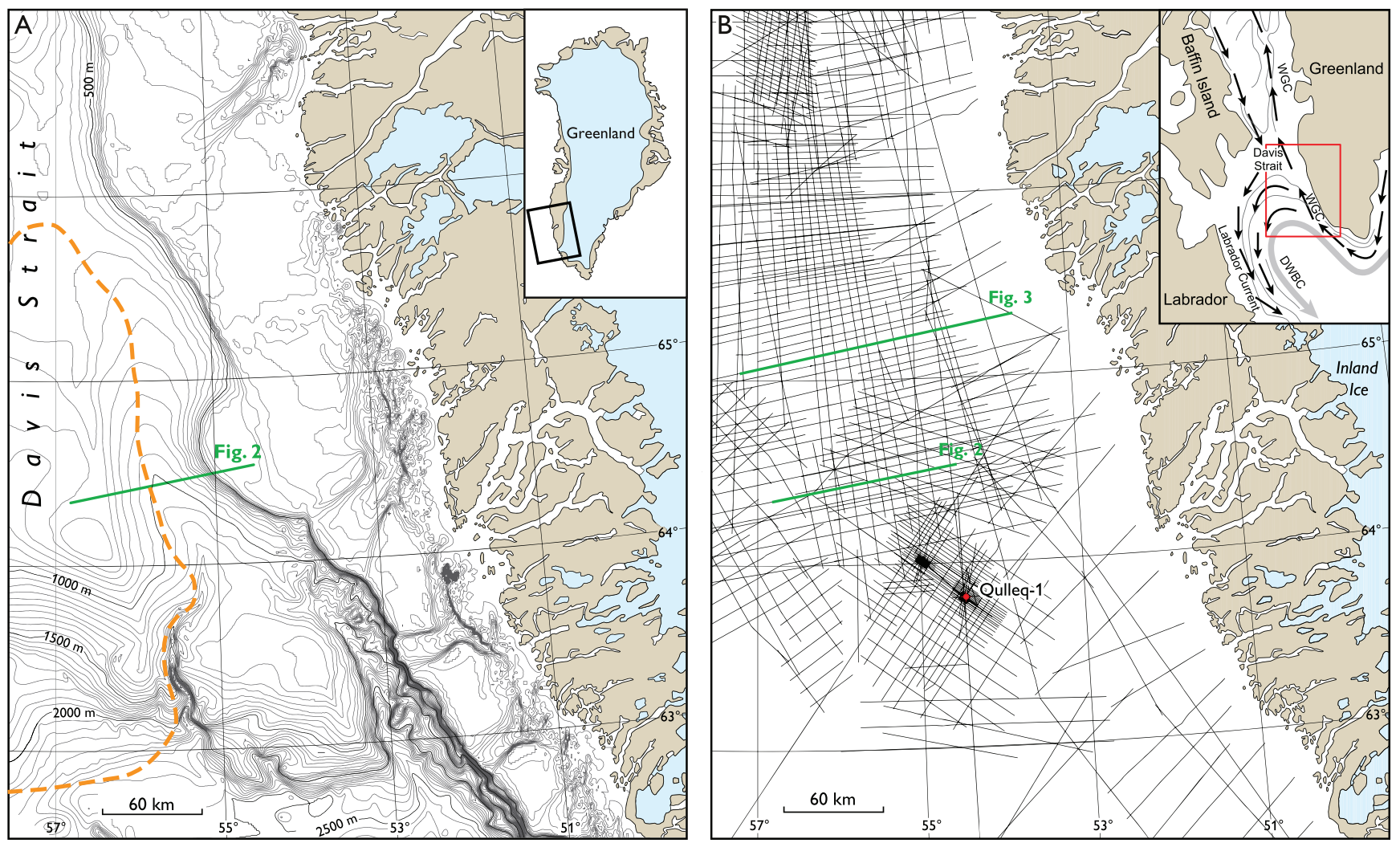

Figure $1 \mid$ (a) Bathymetry of the study area together with the outline of the main body of the Davis Strait Drift Complex (DSDC, orange), and location of the seismic section shown in Fig. 2. The basin in question forms the seabed depression between the shelf break and the drift crest. The insert map shows the regional setting of the study area and present-day extent of the Greenland Ice Sheet. (b) Study area with the grid of seismic lines used for this study. Also shown is the location of exploration well Qulleq-1 which provided the base for the seismo-stratigraphic framework as previously published $^{10}$. The green lines mark the location of the seismic examples shown in Figs. 2 and 3. The inset map shows the pattern of the present-day main current systems, both shallow (small arrows) and deep water (thick arrow). WGC $=$ West Greenland Current; DWBC $=$ Deep Western Boundary Current. For further details, see Ref. 11. Bathymetry compiled by GEUS. Maps produced by GEUS.

more to the north. Common for all GDF units are the timing of the appearance of the oldest one (GDF 1), which based on the regional seismo-stratigraphic model $^{10}$ is assigned to have an early Pliocene age.

\section{Discussion}

An early Pliocene age of GDF 1 is supported by records of ice-rafted materials with Greenlandic provenance documented by ODP drilling Leg $105^{13}$ and comparable to the timing of glacier formation on Iceland ${ }^{14}$, but notably postdates the first occurrence of drop stones off south-eastern Greenland around $7 \mathrm{my}$ ago $^{15}$. The Neogene drop stone sequence from this area has been interpreted to reflect the results of three major glaciations of southeast Greenland between 2.0 and 5.3 my ago. This is supported by the results from ODP Site 987 on the east Greenland Scoresby Sund Fan, revealing glacial debris flows back to about 5 my ago ${ }^{16}$. Based on our seismo-stratigraphy ${ }^{10}$, and supported by the age of the first major coarse-sand peak recorded at ODP Site 918 off Southeast Greenland ${ }^{17}$, we propose an age of near $4.6 \mathrm{my}$ for GDF 1. This age is close to the timing of a negative excursion observed in the time-adjusted global sea level curve $^{18,19}$ suggesting a prominent glaciation event at Northern and Southern high latitudes. These various sources of evidence make us conclude that the first extreme shelf edge glaciation of southern Greenland can be dated between 4.4 and $4.6 \mathrm{my}$. A full and extreme southern Greenland glaciation at that time does, however, not imply that a permanent ice sheet necessarily has existed here since. Major GIS reductions can be assumed during subsequent Pliocene warming between $3.6 \mathrm{my}$ and $2.6 \mathrm{my}^{20}$ and sometime later in the Pleistocene ${ }^{21}$.

As for the youngest GDF 5 unit, we tentatively assign an age corresponding to the Saale glaciation (c. 0.16 my; Marine Isotope Stage 6).This glaciation was characterized by an extreme northern hemisphere ice sheet expansion ${ }^{22}$, and must have been responsible for the production of giant, deep-drafted icebergs originating from southern Greenland ice streams ${ }^{23}$. For information on younger, postSaale deposits we may refer to the Methods section below. In between these oldest and youngest GDF episodes, glacial advances had resulted in a significant sediment input to the shelf and upper slope, but during this long period only three glaciations produced an extensive ice sheet responsible for the deposition of basinal GDF units. Using our seismo-stratigraphic model we can not assign with high confidence a more specific age to each of these three GDF units. Still, based on recent GIS modelling ${ }^{24}$ we suggest that GDF 2 could originate from the earliest Quaternary glaciation era (c. $2.5 \mathrm{my}$ ). A shelf edge glaciation during this period could explain the increased accumulation of coarse sand off southeast Greenland dated at ODP site 918 between ca. 2.5 and $2.0 \mathrm{my}$ ago $^{15}$. For reason of climate warmth both the Mid-Pliocene and early Pleistocene $e^{20,25}$ may be ruled out for age consideration of one of the remaining GDF units (GDF 3 and 4). The same may apply to the 'early Brunhes' era, ca. 0.40-0.75 my, when inter-hemispheric climate asymmetry appears to have been larger, and climate belt and ocean fronts were displaced to the north ${ }^{26-28}$. During this period ice-free interglacial conditions with more abundant vegetation may have been widespread in 
TWT sec.

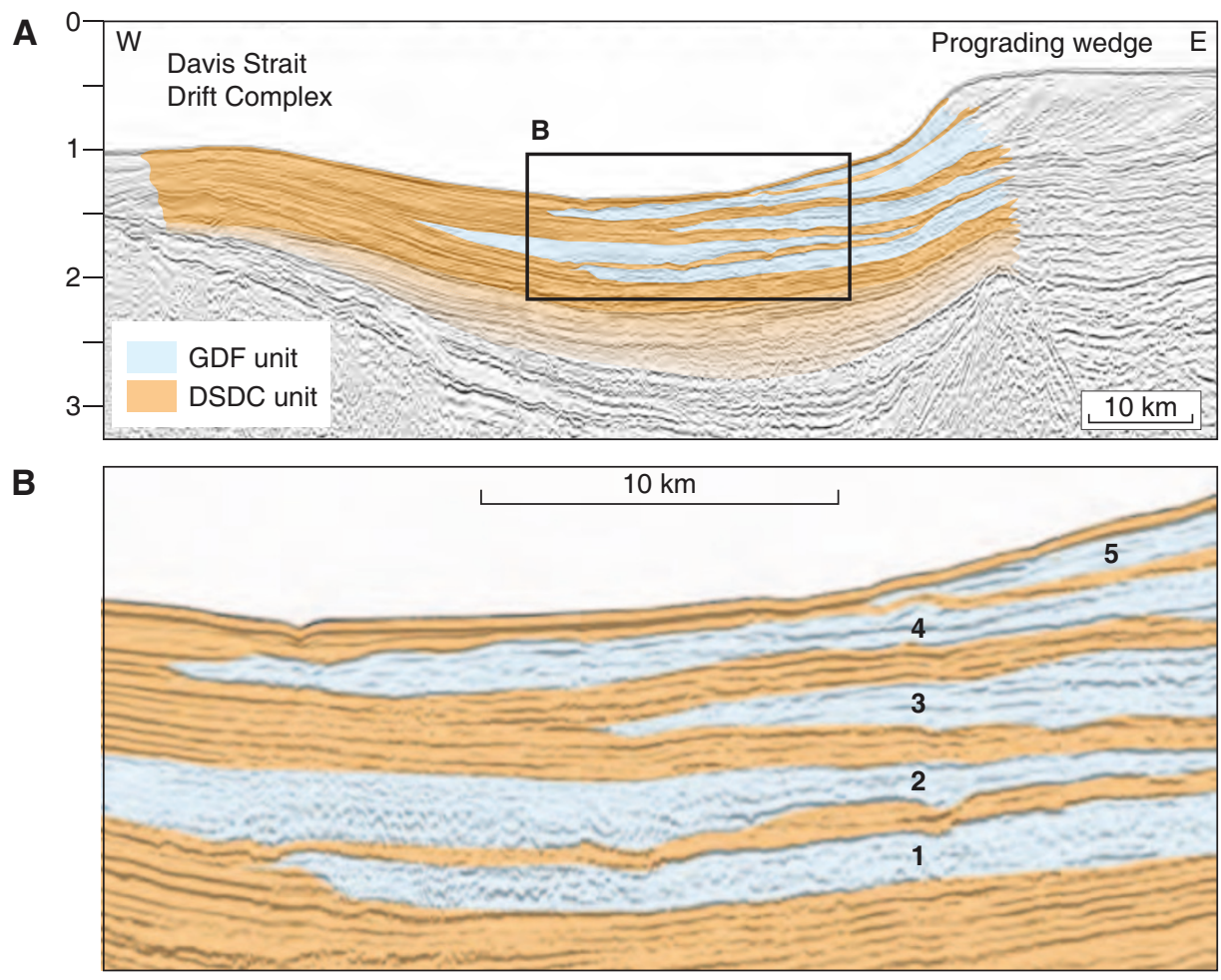

Figure $2 \mid$ Overview (A) and zoom (B) of seismic section crossing the basin offshore Southwest Greenland, extending from the glacigenic prograding wedge deposits on the Greenland shelf in the east to the current-dominated Davis Strait Drift Complex (DSDC) deposits in central Davis Strait in the west. The seismic section illustrates the chaotic and semi-transparent appearance of the five major glacigenic debris flow (GDF) units (blue) identified within the DSDC deposits (orange). The five GDF units are labelled 1 to 5 from bottom to top. The seismic section documents that GDF depositional processes can extend over distances of at least $60 \mathrm{~km}$ from the base of the slope. For location - see Fig. 1.

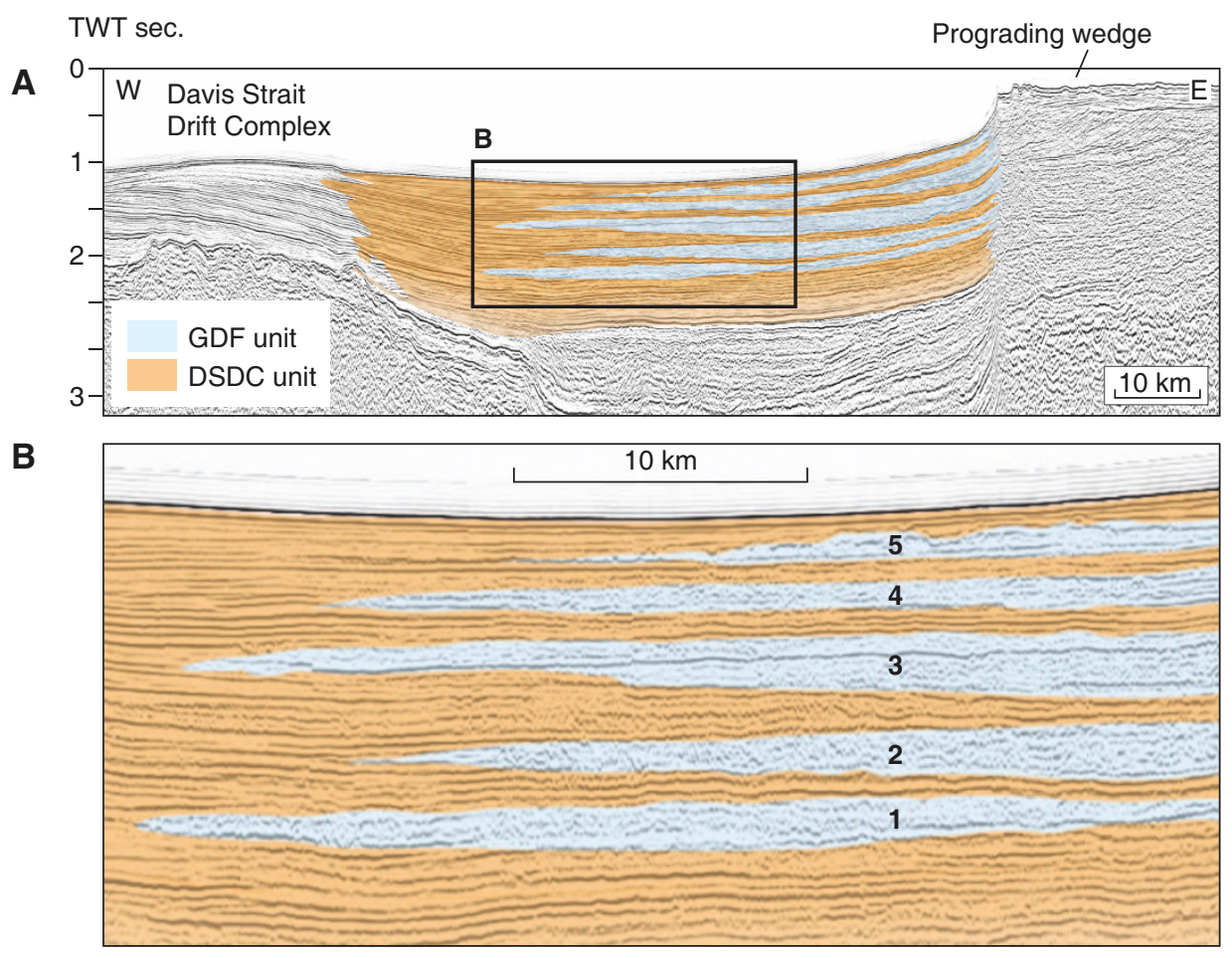

Figure 3 Overview (A) and zoom (B) of seismic section crossing the basin offshore Southwest Greenland, extending from the glacigenic prograding wedge deposits on the Greenland shelf in the east to the current-dominated Davis Strait Drift Complex (DSDC) deposits in central Davis Strait in the west. Location of the seismic section is shown in Fig. 1. For seismic facies interpretation, see Fig. 2. This section illustrates that a similar seismic scenario with five GDF units is still present further to the north. In some cases the GDF units suggest a 2-stage formation as indicated by an intercalated continues reflection horizon (e.g. Unit 3 in the lower panel B). This we attribute to ice margin fluctuations across the shelf edge associated with a stadial-interstadial climate shift. 
southern Greenland $\mathrm{d}^{21}$. Based on our seismo-stratigraphic model we may infer that GDF 3 was deposited after about $1.5 \mathrm{my}$ ago, but further data lack for assigning a more precise age.

The seismic records (Figs. 2, 3) suggest a close timing for GDF 4 and GDF 5, which could imply that these may represent an Elster (GDF 4) - Saale (GDF 5) complex. Such a close timing may also be inferred from the coarse sand mass accumulation record of ODP site $918^{15}$ showing continuously high accumulation rates during the latter period.

Regarding the GDF frequency, it is noteworthy that seismic records of the East Greenland margin further north display six units that likewise were identified as representing Plio-Pleistocene phases of extensive ice sheets ${ }^{29}$. This larger number (six) fits well with our records from shelf areas further north in Davis Strait. An important factor which presumably affects the large-scale GIS morphology and extent of shelf glaciation is (subsurface) advection of warm, Atlanticderived Irminger Sea Water. This mainly influences southern Greenland shelf waters south of Denmark Strait and Davis Strait, respectively ${ }^{11}$. It has been a matter of debate how far the initiation of the North Atlantic Current system has had an impact on large-scale GIS expansion. Also mechanisms such as a decline in atmospheric $\mathrm{CO}_{2}{ }^{30}$ and changed atmospheric circulation patterns due to tectonic uplift of the Rocky Mountains and Himalaya ${ }^{31}$ have been proposed. The latter changes may have affected the cyclone tracks and precipitation patterns over the North Atlantic. It would be beyond the scope of this study to discuss these possible trigger mechanisms of the early Pliocene GIS expansion in more detail. Within this context it is, however, worth noting that a recent study shows an early Pliocene maximum ocean temperature similar as today ${ }^{32}$.

Our findings show that although the late Neogene and Quaternary oxygen isotope record indicate altogether more than 30 glacial stages, only relatively few (five) were characterized by a GIS geometry covering the entire shelf offshore southern Greenland. Greenland shelf areas more to the north are likely to have experienced a larger number of shelf edge glaciations. We estimate an age of around $4.5 \mathrm{my}$ for the oldest southern Greenland shelf edge glaciation and conclude that such extreme GIS expansions did occur here only three times within the past $1.5 \mathrm{my}$, the last event probably corresponding to the Saale glaciation (Marine Isotope Stage 6). Our findings demonstrate the large natural variability of GIS dynamic behaviour with extreme boundary conditions that apparently have changed through time. Grasping the entire range of natural variability is a precondition for improving modelling of future GIS behaviour.

\section{Methods}

A large digital database of conventional 2D seismic reflection data, with a line spacing varying between 5 and $10 \mathrm{~km}$, was used for the study. The database comprises data from a series of individual surveys carried out since the 1980's. Stratigraphic information from the exploration well Qulleq-1 was used for seismic-to-well calibration.

We distinguish between a parallel high-amplitude seismic reflection pattern and a chaotic and semi-transparent reflection pattern. The parallel reflection pattern originates primarily from bottom current deposition, but can also indicate turbidite deposition. To differentiate between these two types of deposits is not always easy. However, in both cases there is seismically a marked difference with the GDF units that are characterized by a chaotic seismic reflection patterns or a semi-transparent appearance without any distinct continuous internal reflections. In contrast to melt-water generated turbidite deposits, the GDF units can be primarily related to sedimentary processes associated with shelf edge glaciation, providing thus a sedimentary record of such extreme glaciations. Further, the GDF can be distinguished from non-glacigenic slide and slump deposits by the lack of up-slope slide scars. Evidence for the latter is entirely lacking in our study area.

The seismic vertical resolution is ca. $10 \mathrm{~m}$, which implies that an upper, post-Saale sediment unit less than about $10 \mathrm{~m}$ thick cannot be recognized on the seismic records. Sediment core data confirm the presence of such a post-Saale unit in the basin ${ }^{33}$, which for the LGM yields a well-stratified sequence clearly lacking any GDF signature. This is supported by studies on the Southwest Greenland shelf that demonstrate that during the LGM the position of the GIS was on the mid shelf $^{6}$.
1. Wolf, T. C. W. \& Thiede, J. History of terrigenous sedimentation during the past 10 m.y. in the North Atlantic (ODP Legs 104 and 105 and DSDP Leg 81). Mar. Geol. 101, 83-102 (1991).

2. Winkler, A., Wolf-Welling, T. C. W., Stattegger, K. \& Thiede, J. Clay mineral sedimentation in high latitude deep-sea basins since the Middle Miocene (ODP Leg 151, NAAG). Int. J. Earth Sci. 91, 133-148 (2002).

3. Eldrett, J. S., Harding, I. C., Wilson, P. A., Butler, E. \& Roberts, A. P. Continental ice in Greenland during the Eocene and Oligocene. Nature 446, 176-179 (2007).

4. North Greenland Ice Core Project (NorthGRIP) members. Nature 431, 147 (2004).

5. Feyling-Hansen, R. W., Funder, S. \& Petersen, K. S. The Lodin Elv Formation, a Plio-Pleistocene occurrence in Greenland. Bull. Geo. Soc. of Denmark 31, 81-106 (1983).

6. Funder, S. et al. Quaternary Glaciations: Extent and Chronology II. (Elsevier, Amsterdam) 425-430 (2004).

7. Nielsen, T. et al. A comparison of the NW European glaciated margin with other glaciated margins. Mar. \& Petr. Geol. 22, 1149-1183 (2005).

8. Dowdeswell, J. A., Elverhøi, A. \& Spielhagen, R. Glacimarine sedimentary processes and facies on the Polar North Atlantic margins. Quat. Sci. Rev. 17, 243-272 (1998).

9. Kuijpers, A. et al. Giant iceberg plow marks at more than 1 kilometre water depth offshore West Greenland. Mar. Geol. 246, 60-64 (2007).

10. Nielsen, T., Andersen, C., Knutz, P. C. \& Kuijpers, A. The Middle Miocene to Recent Davis Strait Drift Complex: implications for Arctic-Atlantic water exchange. Geo-Mar. Lett. 31, 419-426 (2011).

11. Cuny, J., Rhines, P. B., Niiler, P. P. \& Bacon, S. Labrador Sea boundary currents and the fate of the Irminger Sea Water. Journal of Physical Oceanography 32, 627-647 (2002).

12. Rasmussen, T. L., Oppo, D. W., Thomsen, E. \& Lehman, S. J. Deep sea records from the southeast Labrador Sea: Ocean circulation changes and ice-rafting events during the last 160,000 years. Paleoceanography 18, 1018-1033 (2003).

13. Aksu, A. et al. Site 645. Proc. ODP, Init. Rep. 105, S. P. 61-418 (1987).

14. Geirsdóttir, A., Miller, G. H. \& Andrews, J. T. Glaciation, erosion, and landscape evolution of Iceland. J. of Geodynamics 43, 170-186 (2007).

15. Larsen, H. C. et al. Seven Million Years of Glaciation in Greenland. Science 264, 952-955 (1994)

16. Channell, J. E. T. et al. Age Models for Glacial Fan Deposits off East Greenland and Svalbard (Sites 986 and 987). Proceedings Ocean Drilling Program, Scientific Results 162, 149-166 (1999).

17. Kudless St. John, K. E. Data report: Site 918 IRD mass accumulation rate record, Late Miocene-Pleistocene. Pro. ODP, Sci. Results 163, 163-166 (1999).

18. Haq, B., Hardenbol, U. \& Vail, P. R. Mesozoic and Cenozoic chronostratigraphy and cycles of sea-level change. Society of Economic Paleontologists and Mineralogists, Spec. Publ. 42, 72-108 (1988).

19. Cande, S. C. \& Kent, D. V. Revised calibration of the geomagnetic polarity time scale for the Late Cretaceous and Cenozoic. J. of Geophy. Res. 100, 6093-6096 (1995).

20. Salzmann, U. et al. Climate and environment of a Pliocene warm world. Palaeogeography, Palaeoclimatology, Palaeoecology 309, 1-8 (2011).

21. Willerslev, E. et al. Ancient Biomolecules from Deep Ice Cores Reveal a Forested Southern Greenland. Science 317, 111-113 (2007).

22. Colleoni, F. On the Late Saalian glaciation (160-140 ka)-a climate modelling study. PhD thesis, Stockholm University, Inst. of Geology and Geochemistry Report 335, pp 53 (2009).

23. Kuijpers, A. \& Werner, F. Extremely deep-draft iceberg scouring in the glacial North Atlantic. Geo-Mar. Lett. 2, 383-389 (2007).

24. Solgaard, A. M., Reeh, N., Japsen, P. \& Nielsen, T. Snapshots of the Greenland ice-sheet configuration in the Pliocene to early Pleistocene. J. Glacio. 57, 871-880 (2011).

25. Thiede, J. et al. Late Cenozoic history of the polar North Atlatic: Results from Ocean Drilling. Quat. Sci. Rev. 17, 185-208 (1998).

26. de Vernal, A. \& Hillaire-Marcel, C. Natural Variability of Greenland Climate, Vegetation, and Ice Volume During the Past Million Years. Science 320, 1622-1625 (2008).

27. Jansen, J. H. F., Kuijpers, A. \& Troelstra, S. R. A Mid-Brunhes Climatic Event: Long-Term Changes in Global Atmosphere and Ocean Circulation. Science 232, 619-622 (1986)

28. Kuijpers, A. Southern Ocean circulation and global climate in the Middle Pleistocene (early Brunhes). Palaeogeography, Palaeoclimatology, Palaeoecology 76, 67-83 (1989)

29. Vanneste, K., Uenzelmann-Neben, G. \& Miller, H. Seismic evidence for long-term history of glaciation on central East Greenland shelf south of Scoresby Sund. Geo-Mar. Lett. 15, 63-70 (1995).

30. Lund, D. J., Foster, G. L., Haywood, A. M. \& Stone, E. J. Late Pliocene Greenland glaciation controlled by a decline in atmospheric $\mathrm{CO}_{2}$ levels. Nature 454 , 1102-1105 (2008).

31. Ruddiman, W. F. \& Kutzbach, J. E. Forcing of Late Cenozoic Northern Hemisphere climate by plateau uplift in southern Asia and the western American Rocky Mountains. J. Geophys. Res. 94, 18409-18427 (1989).

32. Fedorov, A. V., Brierley, C. M., Lawrence, K. T., Liu, Z., Dekens, P. S. \& Ravelo, A. C. Patterns and mechanisms of early Pliocene warmth. Nature 496, 43-49 (2013). 
33. Knutz, P. C., Ebbesen, H., Christiansen, S., Sicre, M.-A. \& Kuijpers, A. A triple stage deglacial retreat of the southern Greenland Ice Sheet driven by vigorous Irminger Current. Paleoceanography 26, PA3204 (2011).

\section{Acknowledgements}

We acknowledge the Geological Survey of Denmark and Greenland (GEUS) for the opportunity to spend research time and to utilize the extensive seismic data archive of the Survey. For further support, we thank the Danish Research Agency (TROPOLINK project, grant no. 09-069833/FNU).

\section{Author contributions}

T.N. is responsible for the seismic interpretation and A.K. for chronological aspects and climate-related issues. Both authors contributed equally to the conclusion and writing of the paper.

\section{Additional information}

Competing financial interests: The authors declare no competing financial interests.

License: This work is licensed under a Creative Commons

Attribution-NonCommercial-NoDerivs 3.0 Unported License. To view a copy of this license, visit http://creativecommons.org/licenses/by-nc-nd/3.0/

How to cite this article: Nielsen, T. \& Kuijpers, A. Only 5 southern Greenland shelf edge glaciations since the early Pliocene. Sci. Rep. 3, 1875; DOI:10.1038/srep01875 (2013). 